\title{
REFLEXÕES E ANÁLISE SOBRE O PROCESSO DE PRECARIZAÇÃO DO TRABALHO NA CONTEMPORANEIDADE
}

\section{Diego Salomão Candido de Oliveira Salvador ${ }^{1}$}

Resumo: Tendo em vista o fato de a urbanização do Rio Grande do Norte, especificamente do eixo rodoviário Natal-Caicó, estar sendo alicerçada na expansão da pobreza e na precarização do trabalho, refletimos sobre o processo de precarização do trabalho na contemporaneidade, analisando a existência desse processo no território potiguar e no eixo Natal-Caicó. A análise que realizamos evidencia que vem ocorrendo geração de empregos, mas falta qualidade a esses empregos, tendo-se em vista que eles nem sempre garantem direitos sociais aos trabalhadores empregados, remuneram mal a maioria deles, são efêmeros quanto ao tempo em que os trabalhadores permanecem empregados e determinam dedicação quase exclusiva no decorrer da semana. Além disso, a quantidade de empregos gerados não atende à demanda total por trabalho da população economicamente ativa. Destarte, há muitos trabalhadores desempregados, sendo que alguns nunca estiveram empregados, já ingressando no mercado de trabalho por meio de ocupações da economia não hegemônica.

Palavras-chave: Precarização do trabalho; Rio Grande do Norte; Eixo rodoviário Natal-Caicó.

\section{REFLECTIONS AND ANALYSIS ON THE PROCESS OF PRECARIOUS WORK IN CONTEMPORARY TIMES}

\begin{abstract}
In view of the fact that urbanization of Rio Grande do Norte, specifically of the road axis Natal-Caicó, being rooted in the expansion of poverty and in precarious work, we reflect on the process of precarious work in contemporary times, analyzing the existence of that process in the territory of Rio Grande do Norte and in the axis Natal-Caicó. We conducted analysis shows that job creation has taken place, but the quality of these jobs, having in mind that they don't always guarantee social rights to employees, pay off bad most of them, are ephemeral as the time in which workers remain employed and determine almost exclusive dedication during the week. In addition, the number of jobs generated does not meet the total demand for work of the economically active population. Thus, there are many unemployed workers, and some have never been employed, since joining in the job market through occupations of not hegemonic economy.
\end{abstract}

Keywords: Precarious work; Rio Grande do Norte; Road axis Natal-Caicó.

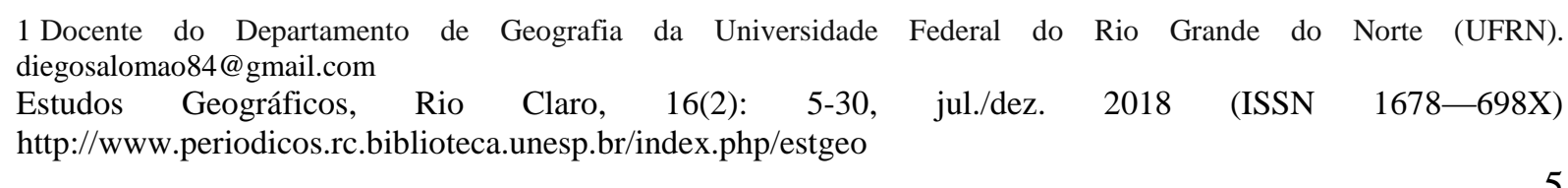




\section{INTRODUÇÃO}

Neste trabalho, refletimos teoricamente sobre o processo de precarização do trabalho na contemporaneidade, analisando a existência desse processo no território potiguar e, especificamente, no eixo rodoviário Natal-Caicó ${ }^{2}$ (mapa 1), tendo em vista o fato de a urbanização do Rio Grande do Norte, especificamente do eixo Natal-Caicó, estar sendo alicerçada na expansão da pobreza e na precarização do trabalho, assim como pelo fato de o crescimento das cidades desse eixo vir contribuindo para a amplificação da economia desenvolvida pelos pobres, evidenciando a sua importância múltipla.

Para atingir o objetivo definido para o trabalho, realizamos reflexões teóricas sobre o processo de precarização do trabalho na contemporaneidade concatenadas à análise desse processo no território potiguar, trazendo à tona dados estatísticos e dados primários ${ }^{3}$ sobre o mercado de trabalho do Rio Grande do Norte e, especificamente, do eixo rodoviário Natal-Caicó.

\footnotetext{
${ }^{2}$ No Rio Grande do Norte existem quatro eixos rodoviários que macroestruturam o território: o Natal-Fronteira Paraibana, utilizado para o transporte de passageiros e para o escoamento de balas, chapas plásticas, tecidos de algodão, granito, tungstênio e açúcar, em direção ao Porto de Suape e a Recife; o Natal-Macau, com utilização para transporte de passageiros e de carga de materiais de construção (brita, cal), combustível para aviação e automóveis bem como equipamentos para parque eólico; o Natal-Mossoró, utilizado para transporte de passageiros e de carga de frutas, castanha de caju, tecidos de algodão, produtos animais impróprios para alimentação humana, lagosta, peixes, camarão, tungstênio e balas, em direção ao Porto de Pecém, a Fortaleza e a Natal, e de sal, para abastecimento do mercado estadual ou regional, sendo que, para o escoamento desse produto, há uma importante conexão do eixo Natal-Mossoró com o Porto de Areia Branca; e o Natal-Caicó, com utilização, sobretudo, para o fluxo de passageiros, contudo também evidenciando o transporte de carga de produtos têxteis e alimentícios em pequena quantidade.

Adotamos o eixo rodoviário Natal-Caicó como recorte de análise devido ao fato desse subsistema de movimentos do território potiguar interligar municípios do interior e do litoral do estado, se destacar pelos fluxos intermunicipais de passageiros e se caracterizar por cidades cujo centro econômico importante é a rodovia que as atravessa, sendo a rodovia margeada, sobretudo, por diversas atividades econômicas desenvolvidas por trabalhadores pobres.

${ }^{3}$ Os dados primários analisados são decorrentes de pesquisa de campo realizada no eixo rodoviário Natal-Caicó, entre os meses de agosto de 2013 e janeiro de 2014, quando aplicamos questionário com 148 responsáveis por atividades econômicas não hegemônicas, cujos dados nos possibilitam refletir sobre a contribuição dessas atividades para a ocupação de muitos trabalhadores.

Estudos Geográficos, Rio Claro, 16(2): 5-30, jul./dez. 2018 (ISSN 1678-698X) http://www.periodicos.rc.biblioteca.unesp.br/index.php/estgeo
} 
Reflexões e análise...

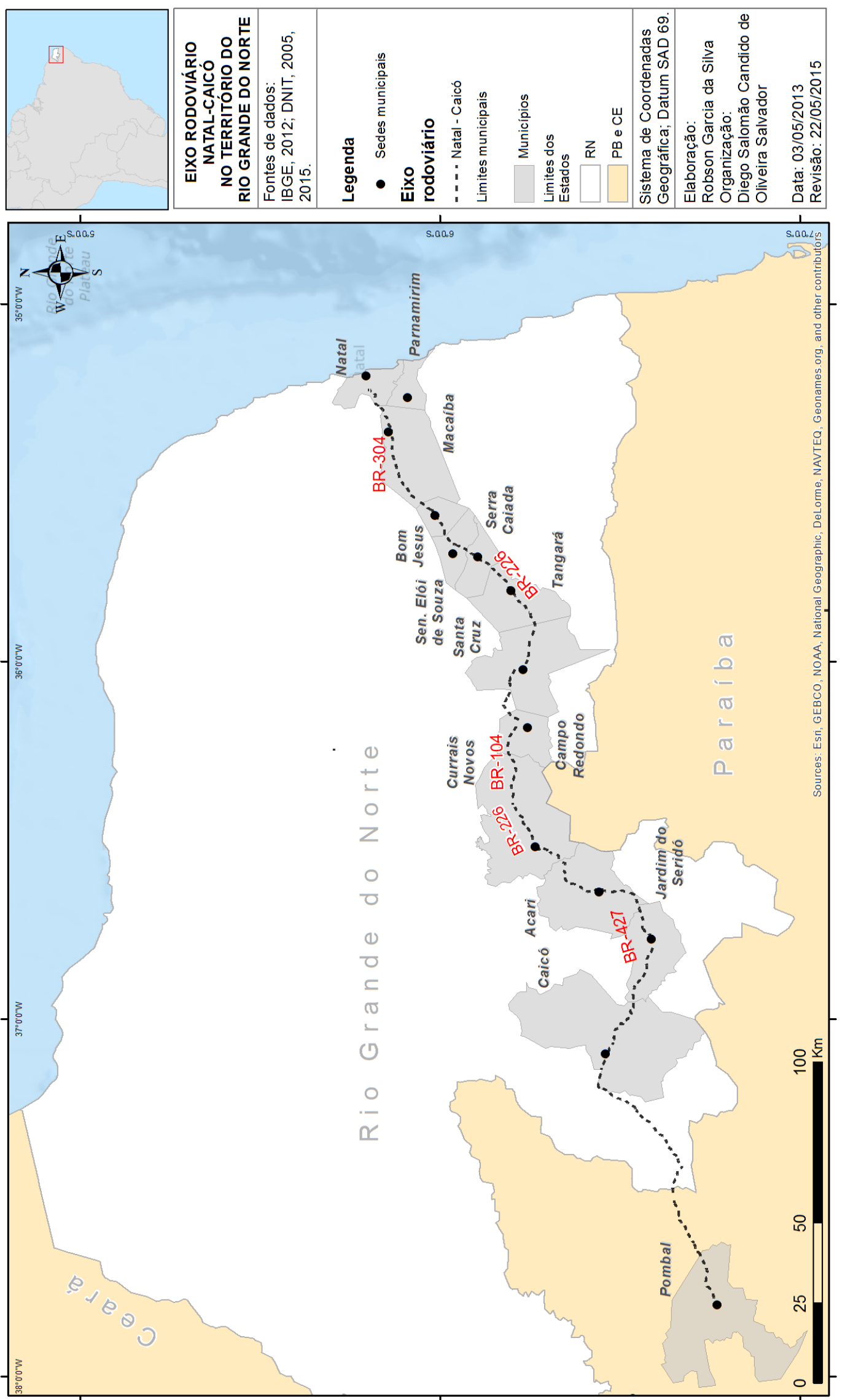

Mapa 1 - Eixo rodoviário Natal-Caicó no território do Rio Grande do Norte Organização: Diego Salomão C. O. Salvador, 2013.

Cartografia: Robson Garcia da Silva, 2013.

Estudos Geográficos, Rio Claro, 16(2): 5-30, jul./dez. 2018 (ISSN 1678-698X) http://www.periodicos.rc.biblioteca.unesp.br/index.php/estgeo 


\section{A ACUMULAÇÃO FLEXÍVEL DE CAPITAL COMO FUNDAMENTO DA INTENSIFICAÇÃO DA PRECARIZAÇÃO DO TRABALHO}

As consequências do neoliberalismo ${ }^{4}$ sobre 0 mundo do trabalho intensificam o processo de precarização do trabalho, por meio da geração de desemprego, da substituição de empregos por ocupações, da elevação da produtividade e da diminuição dos rendimentos bem como da flexibilização dos direitos trabalhistas. Tal processo metamorfoseia a questão social (CASTEL [1995] 2009), ampliando o individualismo e a competitividade nas relações sociais e trazendo à baila a corrosão do caráter $^{5}$ (SENNETT, 2005) e a banalização da exclusão social ${ }^{6}$ (SANTOS, 2007). Assim, ao analisarmos a precarização do trabalho, estamos considerando esse processo como extremamente conectado à chamada questão social e a sua transformação.

A precarização do trabalho é um processo que se intensifica atrelado à modernização econômica do território de acordo com a acumulação flexível de capital. Essa acumulação é implementada, sobretudo, a partir da década de 1970, como estratégia para combater a "rigidez" do regime de acumulação capitalista que predominou da Revolução Industrial (século XVIII) até o final da Segunda Guerra Mundial (1939-1945) (DIAS, 2012). Assim, pela concepção da "flexibilização", agentes hegemônicos do mercado, com o apoio monetário, financeiro, normativo e de capital fixo de agentes estatais e o sufrágio científico de agentes acadêmicos, adensaram as inovações técnicas, desregulamentaram o mercado de trabalho privilegiando a instância econômica, amplificaram a circulação de mercadorias, com a aplicação das inovações técnicas na produção de sistemas de engenharia em determinados territórios, aceleraram o consumismo de objetos modernos e de mecanismos financeiros nas diferentes classes sociais, inclusive entre os pobres, e conferiram ao sistema financeiro uma importância ímpar para o desencadeamento de mecanismos que favoreçam a acumulação de capital pela economia hegemônica.

Dessa maneira, a modernização territorial fundamentada na acumulação flexível de capital vem conferindo "liberdade" às empresas da economia hegemônica para, formalmente, ajustarem a quantidade do pessoal empregado e a forma como ocorre o emprego de trabalhadores de acordo com as flutuações da demanda por seus produtos. Para Krein (2007), essa liberdade empresarial ajusta as relações e o mercado de trabalho à chamada "nova ordem social, econômica e política", que, na verdade, é constituída de políticas econômicas restritivas voltadas ao controle da inflação e à elevação do desemprego.

Nessa perspectiva, podemos compreender a acumulação flexível de capital como corolário de uma opção política de Estado neoliberal cujas medidas macroeconômicas $^{7}$ potencializam a escassez do emprego e contribuem para a

\footnotetext{
${ }^{4}$ Compreendemos o neoliberalismo do mesmo modo que Abílio (2011): um rearranjo de poder provocado pelas classes dominantes entre as décadas de 1960 e 1980, com o escopo de elevar os lucros decorrentes da exploração do trabalho.

${ }^{5}$ De acordo com Sennett (2005), a corrosão do caráter se evidencia pelas perdas de valor, de sentido, da lealdade e do compromisso mútuo nas relações entre os homens. Tais perdas fragmentam os laços outrora existentes entre os trabalhadores, individualizando-os e colocando-os à deriva diante da força dos agentes hegemônicos do mercado capitalista.

${ }^{6}$ Santos (2007) defende que os desempregados que não têm mais possibilidade de serem empregados são pessoas que, além do sistema de desigualdade, são também submetidas ao sistema de exclusão, pois são incluídas de maneira subordinada na dinâmica socioeconômica e excluídas do contrato social de trabalho.

${ }^{7}$ Dentre essas medidas, Oliveira (2009, p. 125) cita: “[...] contração da emissão de moeda, elevação da taxa de juros básicos, redução de impostos sobre as rendas mais elevadas, desregulamentação do mercado de trabalho, desregulamentação do Estudos Geográficos, Rio Claro, 16(2): 5-30, jul./dez. 2018 (ISSN 1678-698X) http://www.periodicos.rc.biblioteca.unesp.br/index.php/estgeo
} 
precarização das condições de trabalho, aspectos característicos da "[...] própria lógica do sistema de metabolismo social do capital [...], desde a gênese do capitalismo" (ANTUNES, 2013, p. 27), mas tornados mais densos e dominantes, em termos sociais e territoriais, desde a década de 1970.

Além da escassez de empregos, potencializa-se também a precarização dos poucos empregos existentes e/ou gerados, já que a acumulação flexível é calcada na conexão entre crescimento da economia e exploração desmedida do trabalho (ANTUNES, 1998). Nesses dois sentidos, os agentes hegemônicos do mercado, além de destruírem vários postos de emprego, precarizam os existentes ou os criados, exigindo qualificação dos trabalhadores, individualização de suas práticas laborais e ofertando-Ihes rendimentos cada vez mais desvalorizados diante da pressão inflacionária que caracteriza a economia nacional. Assim sendo, concordamos com Itikawa (2006) e com Vasapollo (2006) quando afirmam que a utilização do termo "flexibilização" para as relações de trabalho nada mais faz do que esconder a precarização do trabalho, inclusive com a eliminação ou o enfraquecimento de direitos trabalhistas e a difusão do trabalho irregular, sem garantias.

Diante da perversidade da acumulação flexível de capital para com o mundo do trabalho, Krein (2007, p. 07) enfatiza que, na década de 1990, em países centrais, como França e Inglaterra, argumentou-se e, de certo modo, agiu-se pelo fim da flexibilização das relações de trabalho, com a alegação de que ela não havia apresentado os efeitos esperados e de que era importante investir no sistema de proteção social, a fim de favorecer a própria competitividade desses países. Contudo, ainda na década de 1990, organismos internacionais, como o Fundo Monetário Internacional (FMI), e grandes empresas retomaram de maneira avassaladora a tese da flexibilização, apregoando o aumento da jornada de trabalho sem a respectiva elevação dos rendimentos dos trabalhadores. Em troca, tais agentes hegemônicos do mercado propuseram e ofertaram a "[...] manutenção de um certo nível de emprego".

Desse modo, a acumulação flexível de capital continua a reger o estágio atual do capitalismo, fazendo com que esse sistema seja, cada vez mais, desprovido de orientação humanamente significativa e sua lógica societal seja calcada no valor de troca das coisas, e não no valor de uso, gerando ou intensificando amplas desigualdades sociais e territoriais.

\section{BANALIZAÇÃO SOCIAL, ECONÔMICA E TERRITORIAL DA PRECARIZAÇÃO DO TRABALHO}

A precarização do trabalho é um processo que, hoje, afeta todas as relações de trabalho: tanto as ocorridas no âmbito do circuito superior quanto no do circuito inferior da economia urbana; tanto as referentes a trabalhadores qualificados

\footnotetext{
comércio externo, desregulamentação do mercado financeiro, redução da participação do Estado na economia pelo enxugamento dos gastos sociais e privatizações de empresas estatais [...]".

${ }^{8}$ Conforme a teoria dos circuitos da economia urbana dos países subdesenvolvidos (SANTOS, 1978a), a dinâmica econômica da cidade desses países é segmentada em dois circuitos: circuito superior e circuito inferior. Tais circuitos coexistem no território, por meio de relações de concorrência, de complementaridade e de subordinação do circuito inferior ao circuito superior.

Os circuitos da economia urbana são definidos pelos níveis de capital, de tecnologia e de organização das suas atividades, bem como pelas suas escalas de atuação. O circuito superior da economia urbana do eixo rodoviário Natal-Caicó é definido por atividades de organização burocrática, considerável nível tecnológico e forte necessidade de capital para seu desenvolvimento, como bancos, indústria, comércio e serviços modernos, e atacadistas. Tais atividades têm ampla escala de Estudos Geográficos, Rio Claro, 16(2): 5-30, jul./dez. 2018 (ISSN 1678-698X) http://www.periodicos.rc.biblioteca.unesp.br/index.php/estgeo
} 
quanto as que dizem respeito a trabalhadores com pouca qualificação ou sem qualificação; tanto as referentes aos contratos de emprego com registro em carteira de trabalho quanto às ocupações acertadas sem nenhum vínculo ou registro empregatício.

Esse processo se banaliza socialmente entre os trabalhadores, independentemente das relações de trabalho a que estão submetidos, devido a todas essas relações, na atualidade, serem alicerçadas na acumulação flexível de capital (MÉSZÁROS, 2006). No circuito superior da economia urbana, são empregados trabalhadores que são submetidos, muitas vezes, a perigosas condições de trabalho e/ou a horários de labor flexibilizados de acordo com as necessidades da empresa contratante, não se considerando a situação de vida do empregado. Além disso, os empregados são submetidos a contratos temporários de trabalho, sob baixos níveis de rendimentos e com acesso mínimo a garantias ou direitos trabalhistas. As empresas do circuito superior, com frequência, também apenas ocupam trabalhadores, submetendo-os a estafantes horários de trabalho, sob péssimas condições de labor e pagando-Ihes os mais baixos rendimentos possíveis.

No circuito inferior, a precarização do trabalho é também um traço marcante da organização das atividades. A maioria dos trabalhadores desse subsistema desenvolve suas atividades por conta própria, laborando durante longas jornadas, obtendo baixos rendimentos e não tendo acesso a direitos trabalhistas. Em alguns casos, são contratados trabalhadores sem registro em carteira de trabalho, sob relações calcadas em acordos pessoais, com rendimentos, às vezes, abaixo do mínimo necessário para se viver ou no limite, e sem acesso a benefícios trabalhistas. Hoje, devido à política do Microempreendedor Individual (MEI), há agentes do circuito inferior que vêm tendo acesso a determinados direitos previdenciários, como aposentadoria por tempo de serviço, assim como há aqueles que vêm assinando a carteira de funcionário contratado, fato que não impede que acordos pessoais sejam feitos para flexibilizar a jornada de trabalho ou o pagamento de direitos trabalhistas, como o $13^{\circ}$ salário.

Assim sendo, asseveramos que a precarização do trabalho não é um processo limitado a um circuito econômico, mas, sim, peculiar à totalidade da dinâmica econômica territorial. Além disso, o registro em carteira de trabalho não garante aos trabalhadores a não flexibilização de suas condições e seus direitos trabalhistas. Dependendo do faturamento ou da lucratividade da atividade econômica ou do agente social contratante, os trabalhadores podem ser submetidos a acordos pessoais de trabalho, mesmo que estejam registrados formalmente. Desse modo, a garantia de seus direitos está atrelada, dentre outros fatores, à liberdade que a acumulação flexível de capital confere às empresas do circuito superior para honrar ou não, significativamente, seus deveres, como também ao nível de faturamento ou lucro obtido pelas atividades do circuito inferior.

Igualmente, a banalização da precarização do trabalho é econômica e territorial. Econômica porque permeia as atividades de todos os ramos da economia: agropecuárias, produtivas, comerciais e/ou de serviços. Alves (2001) assevera que não há, contemporaneamente, em escala nacional, nenhum segmento econômico

atuação, relacionando-se com os âmbitos regional, nacional e até mesmo global. Já o circuito inferior desse eixo rodoviário é integrado por atividades de organização criativa e pouco ou nada burocrática, de tecnologia utilizada em nível inferior ao que ocorre naquele circuito e de menor necessidade de capital para o funcionamento, sendo, em contrapartida, imprescindível a intensidade de trabalho. É o caso das pequenas produções de alimentos, do pequeno comércio e dos serviços diversos fornecidos a varejo. As atividades não hegemônicas vêm, ultimamente, expandindo sua escala de atuação, contudo as relações com o lugar continuam importantes.

Estudos Geográficos, Rio Claro, 16(2): 5-30, jul./dez. 2018 (ISSN 1678-698X) http://www.periodicos.rc.biblioteca.unesp.br/index.php/estgeo 
que não registre diminuição de empregos de boa qualidade e, concomitantemente, aumento de ocupações precárias. E territorial devido a esse processo afetar todos os países integrados ou não na nova ordem social, econômica e política. Mattoso (1994, p. 21) realça que os países que aceitam tal integração, com ou sem restrições, vêm passando por modernizações territoriais que geram consequências perversas mais ou menos intensas para o mundo do trabalho. Já aqueles que resistem a aderir à ordem neoliberal sofrem sanções das nações e das empresas hegemônicas do mercado mundial, sendo "[...] incapacitados de acompanhar os imperativos da competitividade e excluídos de fluxos tecnológicos, comerciais e/ou financeiros", o que dificulta, de certo modo, suas dinâmicas econômicas e contribui para a precarização de suas relações e de seus mercados de trabalho.

A banalização social, econômica e territorial da precarização do trabalho faz desse processo uma expressão da (re)produção da pobreza, sendo que o aumento do desemprego e das ocupações precárias somado com a diminuição dos rendimentos e dos direitos dos trabalhadores são aspectos que relacionam intrinsecamente o crescimento da pobreza estrutural com a precarização do trabalho, sobretudo nos países subdesenvolvidos.

\section{A SIMETRIA ENTRE PRECARIZAÇÃO DO TRABALHO E POBREZA ESTRUTURAL NOS PAÍSES SUBDESENVOLVIDOS}

O desemprego generalizado e crônico, a crescente competição pelos irrisórios postos de emprego abertos ou ainda existentes, a diminuição das remunerações, o enfraquecimento dos direitos trabalhistas e a monetarização e financeirização de toda a vida associam, de modo simétrico, a precarização do trabalho com a produção da pobreza nos países subdesenvolvidos.

Considerando essa associação e concordando com as concepções de Santos (1978a), entendemos que pobres são aqueles que não têm acesso, de modo regular, aos bens de consumo corrente considerados como o mínimo indispensável em certa sociedade, desenvolvendo, comumente, ações não hegemônicas em busca de sua sobrevivência, com organizações e rendimentos subordinados à economia hegemônica. Trata-se de trabalhadores desempregados ou empregados precariamente, de ocupados sem remuneração fixa ou mal remunerados.

Nos países subdesenvolvidos, tais trabalhadores não têm acesso a certos mecanismos destinados aos desempregados de países desenvolvidos, como o seguro desemprego pago a todos os que estão sem trabalho. Por isso os pobres daqueles países não podem ficar parados sem pensar no dia seguinte, buscando, assim, cotidianamente sua sobrevivência. Santos (1978a) distingue trabalhadores desempregados com certa segurança nos países desenvolvidos de trabalhadores pobres sem segurança nos países subdesenvolvidos.

Sem poder "se dar o luxo" de ficarem "parados", os pobres e desempregados dos países subdesenvolvidos "correm atrás" de sua sobrevivência (SINGER, 2003), caracterizando-se por intensa mobilidade e adaptabilidade de sua mão de obra. Eles se locomovem constantemente pelo território em busca de ocupações intercambiáveis que Ihes proporcionem ganhos sem que sejam necessários capital intensivo e qualificação densa para desenvolvê-las.

Destarte, em termos geográficos, não devemos estudar a pobreza sem considerar que a urbanização dos países subdesenvolvidos é intensificada, Estudos Geográficos, Rio Claro, 16(2): 5-30, jul./dez. 2018 (ISSN 1678-698X) http://www.periodicos.rc.biblioteca.unesp.br/index.php/estgeo 
sobretudo, pela expansão de atividades do circuito inferior, por meio das quais a maioria dos trabalhadores sobrevive com criatividade e resistência e materializa sua situação de pobreza no território usado. Mais do que isso, não devemos estudar a pobreza dissociada do território, sendo imprescindível atentarmos para como os trabalhadores usam o território diante do perverso contexto atual em que, cada vez mais, se precarizam as relações e o mercado de trabalho.

Todavia, há autores que, negligenciando a análise do uso do território pelos pobres diante da escassez de empregos com qualidade e em quantidade, falam na diminuição das desigualdades sociais ou mesmo no fim da pobreza no Brasil nos dias atuais, revelando concepções que se alicerçam em abordagens reducionistas da complexa situação de pobreza vivenciada pela maioria dos trabalhadores.

Conforme Neri (2010), entre 2003 e 2009 houve diminuição das classes D e E (extrema pobreza) e elevação da classe C (pobreza) no Brasil, sobretudo via aumento do consumo propalado entre todas as classes sociais, inclusive entre os pobres. Na visão do economista, esses dados estatísticos revelam diminuição da desigualdade no país com o início da assunção ao desenvolvimento. Contudo, esse ponto de vista é exagerado, porque não leva em conta que o aumento do consumo vem tornando os pobres cada vez mais endividados e subordinados às normas de atividades do circuito superior, fato que remete ao aumento do fosso entre os circuitos da economia urbana e à produção de uma pobreza não mais conjuntural ou pontual, mas, sim, estrutural.

Na mesma perspectiva de compreensão da realidade, Rocha (2013) diz que a pobreza no Brasil vem passando por "forte queda", devido ao fato de o país vivenciar uma conjuntura de crescimento econômico, aumento sustentado da renda, melhoria das condições de vida, acesso a serviços públicos, formalização no mercado de trabalho, pleno emprego, expansão do crédito e redução de preços de bens duráveis. O problema da compreensão de Rocha (2013) é que ela se fundamenta, acima de tudo, em dados estatísticos e em indicadores de linhas de pobreza, apresentando-se, portanto, como extremamente numérica e negligente com a situação territorial dos agentes sociais não hegemônicos. Ao calcar sua compreensão em números, a autora acaba afastando-se da apreensão da dinâmica territorial, não considerando aspectos que hoje estão explícitos na realidade, como a diminuição dos rendimentos dos trabalhadores e dos empregos gerados. Ao contrário do que é dito pela autora, o que está em pleno vigor no país é a precarização do trabalho, com a amplificação das ocupações e a deterioração dos rendimentos e dos direitos dos trabalhadores. Assim sendo, ao invés de falarmos em "queda forte da pobreza", devemos atentar para a produção de uma nova pobreza: a estrutural.

Outrossim, de acordo com Santos (1978b), há autores que defendem que os pobres participam apenas parcialmente do mercado de trabalho, ou mesmo não têm nenhuma função específica na sociedade urbana, por desenvolverem atividades não produtivas. Essa concepção é duplamente equivocada: primeiro porque, longe de serem "afuncionais", os pobres desempenham atividades econômicas cuja organização difere da burocracia das atividades do circuito superior mas nem por isso deixam de ser atividades importantes para a intensificação da urbanização do território dos países subdesenvolvidos sob os imperativos da modernização econômica; e, segundo, porque as atividades não hegemônicas desenvolvidas pelos pobres são importantes também por viabilizarem a acumulação ampla de capital, tanto em nível local, quanto em nível nacional e mundial. Dessa maneira, os pobres agem no funcionamento do atual período do sistema capitalista por proporcionarem

Estudos Geográficos, Rio Claro, 16(2): 5-30, jul./dez. 2018 (ISSN 1678-698X) http://www.periodicos.rc.biblioteca.unesp.br/index.php/estgeo 
acumulação no centro e na periferia, fato que evidencia a produtividade do trabalho no circuito inferior da economia urbana.

A questão central dessas discussões sobre a pobreza é como ela é compreendida. Os autores que negligenciam o uso do território pelos pobres e apreendem a pobreza meramente ou sobretudo por dados estatísticos a consideram, a nosso ver, de maneira reducionista, privilegiando, geralmente, a renda dos trabalhadores. Rocha (2003, p. 13) entende que pobres são "aqueles cuja renda é insuficiente para atender um conjunto de necessidades mínimas na sociedade".

A compreensão reducionista da pobreza não é só pensada por determinados autores, mas também vem sendo adotada pelo Estado na formulação e na aplicação de políticas públicas. Os agentes estatais consideram a pobreza " [...] como uma categoria econômica calculável pelo parâmetro renda", sendo esta a "variável-chave" para a implementação de ações em relação aos pobres (ZAOUAL, 2003, p. 70-71). Se, para os agentes do circuito superior, as ações do Estado são de apoio monetário e também de instalação de capital fixo de acordo com preceitos hegemônicos, para os do circuito inferior tais ações dizem respeito, predominantemente, a programas de transferência de renda, os quais não combatem estruturalmente a desigualdade social e territorial no país e explicitam uma postura extremamente monetária no que tange à pobreza.

Defendemos que a pobreza não deve ser entendida como a mera insuficiência de renda. É imprescindível que a compreendamos sob perspectivas amplas, considerando a situação social, econômica, política, cultural e territorial dos pobres. É extremamente salutar atentarmos para como eles sobrevivem e, assim, como usam o território no atual período. Fazendo isso, teremos condição de entender que "[...] o desemprego pode afetar não apenas a renda dos trabalhadores, mas [...] suas possibilidades quanto ao futuro e disparar formas de luta criativas ou conformismo" (OLIVEIRA, 2009, p. 183).

Do mesmo modo, a compreensão ampla da pobreza nos permite relacionála ao processo de precarização do trabalho, o qual vem constituindo-se em um fundamento da produção de uma nova pobreza: "a pobreza estrutural" (SANTOS, 1978b). Essa nova pobreza é chamada de estrutural porque tem em sua natureza, a ação dos pobres subordinada aos agentes hegemônicos do mercado assim como a banalização da situação de pobreza em todos os países do mundo, desenvolvidos ou subdesenvolvidos, logicamente de maneiras diferentes, porque relacionadas a cada história de uso pretérito e atual do território nacional.

A pobreza estrutural caracteriza-se pela maior participação dos pobres no consumo residencial e/ou na incorporação no trabalho de objetos modernos sem que isso represente uma diminuição da sua dependência para com agentes hegemônicos do mercado e autoridades políticas bem como de sua situação de escassez no que se refere a bens de consumo básicos (alimentos, vestimentas, produtos de higiene) e a serviços essenciais à vida (educação, saúde, saneamento básico, lazer). Uma situação que, de acordo com o pensamento de Salama (1999), caracteriza-se tanto pelos estigmas da sociedade moderna quanto pelo conservadorismo socioeconômico do subdesenvolvimento. Assim sendo, podemos dizer que "[...] ser pobre é participar de uma situação estrutural com uma posição relativa inferior [subordinada] dentro da sociedade como um todo" (Oliveira et. al., 2012, p. 01).

Sendo uma situação relativa não hegemônica dentro da sociedade como um todo, mesmo que o acesso ao consumo de bens modernos ocorra a pobreza Estudos Geográficos, Rio Claro, 16(2): 5-30, jul./dez. 2018 (ISSN 1678-698X) http://www.periodicos.rc.biblioteca.unesp.br/index.php/estgeo 
estrutural escapa às definições de pobreza calcadas somente ou principalmente em quantitativismos. A pobreza estrutural é mais do que baixa renda, é dependência, é privação de capacidades. É uma situação de carência, mas também de luta.

Hoje, a maioria dos trabalhadores sobrevive por meio de atividades do circuito inferior da economia urbana. Lutando diariamente pelo uso do território de maneira menos precária, tais trabalhadores procuram ter acesso a mecanismos financeiros e a mercadorias comercializadas pelo circuito superior para melhorar seu estabelecimento comercial e/ou amplificar a diversidade de produtos ou serviços ofertados à clientela. Com isso, complexificam a organização das atividades não hegemônicas que desenvolvem, mas também se submetem ao pagamento de altíssimas taxas de juros cobradas pelo sistema de crédito financeiro, ficando sujeitos ao endividamento e à inadimplência.

Essa situação vivenciada por agentes do circuito inferior vai de encontro ao discurso político, contemporaneamente em destaque no Brasil, de que a pobreza diminui à medida que ocorre a expansão do consumo. Tal discurso não leva em conta a situação de subordinação dos pobres nas relações e no mercado de trabalho, valorizando demasiadamente o consumismo e não exaltando ou, ao menos, considerando a importância socioeconômica das atividades econômicas desencadeadas pelos pobres.

Além disso, a pobreza estrutural que marca a vida e o trabalho da maioria dos trabalhadores torna necessário que se reconsidere o que, ainda, muitos autores e agentes hegemônicos do mercado ou estatais denominam de "informal" e que, contraditória mas coerentemente, se apresenta como a situação não hegemônica de trabalhadores aos agentes hegemônicos da economia. Souza (2008) frisa que uma discussão importante a ser realizada nos dias atuais não é aquela acerca da informalidade, mas, sim, a referente à nova cultura do trabalho adaptada ao desemprego e ao emprego precário, bem como sobre como o Estado pode prover condições para que pobres se insiram no mercado de trabalho não precariamente.

Outro aspecto da natureza da pobreza estrutural é sua produção mundial, possibilitada pela infiltração nos territórios nacionais de interesses de agentes hegemônicos do mercado internacional. Vasapollo (2006) ressalta que a internacionalização das economias nacionais vem ocorrendo de modo perverso para o mundo do trabalho, gerando desemprego, desigualdades de renda, crescimento substancial dos preços do consumo, enfim precarização das relações e do mercado de trabalho, o que aumenta, em termos escalares, e agrava, em termos sociais, o problema da nova pobreza.

A produção mundial da pobreza estrutural é, de acordo com Santos (1978b), uma produção planejada, para a qual não se buscam remédios, mas, ao contrário, energéticos. As empresas e instituições globais hegemônicas comandam a produção da pobreza estrutural por meio da determinação do consumo, o qual, cada vez mais, se torna um dos objetivos da expectativa de ascensão no âmbito do sistema capitalista. Assim, os referidos agentes hegemônicos têm no consumismo uma poderosa estratégia para pacificar os pobres, ou, em outras palavras, uma hábil manobra para conquistar o povo e ganhar o poder, sem mudar a estrutura deste, isto é, sem colocar o povo no exercício dele. Trata-se de uma estratégia que integra perversamente os pobres no atual contexto da modernização econômica.

Entendendo a pobreza como uma situação planejada, e não como uma fatalidade ou uma normalidade das desigualdades de renda que caracterizam o capitalismo, afirmamos que os agentes produtores da pobreza dizem que ela é "indesejável", mas, em suas ações, consideram-na como "indispensável" (SANTOS,

Estudos Geográficos, Rio Claro, 16(2): 5-30, jul./dez. 2018 (ISSN 1678-698X) http://www.periodicos.rc.biblioteca.unesp.br/index.php/estgeo 
1978b; SILVEIRA, 2009), pois as atividades econômicas desenvolvidas pelos pobres têm contribuído para a intensificação da urbanização sob preceitos hegemônicos, ou seja, sem que haja atenuação da precarização do trabalho e das condições de vida da maioria dos trabalhadores. Assim sendo, ao invés de um resultado indesejado, a pobreza estrutural é uma dívida social.

\section{GÊNESE, INTENSIFICAÇÃO E CONTINUIDADE DA PRECARIZAÇÃO DO TRABALHO NO BRASIL}

Para Druck (2013), a gênese do processo de precarização do trabalho no Brasil pode estar na transição do trabalho escravo para o assalariado, quando já havia considerável precarização da situação dos trabalhadores. Sem atentar para tal transição, Krein (2007) destaca que o mercado de trabalho brasileiro é, historicamente, flexível, caracterizado pelo excedente estrutural de força de trabalho, pelos baixos rendimentos dos trabalhadores, pequena proteção social, acentuado desrespeito aos direitos trabalhistas vigentes e destaque das atividades econômicas não hegemônicas calcadas nas ocupações precárias de trabalhadores.

Não obstante a precarização do trabalho não ser uma novidade no Brasil, ambos os autores também frisam que tal processo vem sendo reconfigurado e ampliado desde a segunda metade do século XX, sobretudo a partir da década de 1970, estando hoje extremamente ajustado com objetivos neoliberais e generalizado social e territorialmente.

Contudo, mesmo que a precarização do trabalho seja uma característica socioterritorial do Brasil, devemos destacar que houve no país um período em que foram feitos esforços no sentido de garantir à maioria dos trabalhadores o acesso ao mercado de trabalho de maneira registrada e com proteção social. De acordo com Corrêa (2010), esse período situa-se entre as décadas de 1930 e 1950, quando ocorreu, de modo inicial, a urbanização do território nacional, assim como foram criadas instituições e institucionalizações para regulamentar formalmente o trabalho, como a criação do Ministério do Trabalho (1930), a institucionalização do Direito do Trabalho e a criação da Justiça do Trabalho (1934) e de um amplo código de leis trabalhistas, que, mais tarde, foram sistematizadas na Consolidação das Leis do Trabalho (CLT), promulgada em 1943. Com a CLT, a carteira de trabalho passou a ser documento obrigatório nas relações empregatícias, como também explicitaramse os seguintes direitos dos trabalhadores empregados: salário-mínimo, férias anuais remuneradas, limitação da jornada de trabalho, proteção do trabalho feminino e do de menores, condições de proteção contra acidentes de trabalho, indenização por dispensa sem justa causa, aposentadoria por tempo de serviço, salário-família e seguro-desemprego.

Contudo, Antunes (2010) ressalta que, a partir da década de 1950, tais esforços foram eclipsados por um novo padrão de acumulação de capital, estruturado na superexploração da força de trabalho, a ponto de, já entre 1950 e 1970, o mercado de trabalho no Brasil ser marcado por baixos salários, conjugados a prolongadas e intensas jornadas de trabalho, num contexto econômico de significativo progresso produtivo, que inseriu o país entre as oito grandes potências industriais de então. Assim, asseveramos que a precarização do trabalho pode não ocorrer pela estagnação econômica, mas pelo dinamismo fundamentado na falta de oportunidades de emprego com qualidade e em quantidade.

Estudos Geográficos, Rio Claro, 16(2): 5-30, jul./dez. 2018 (ISSN 1678-698X) http://www.periodicos.rc.biblioteca.unesp.br/index.php/estgeo 
Na década de 1980, deu-se continuidade ao processo de precarização do trabalho no Brasil, com a implementação mais direta, no território nacional, embora ainda seletiva e limitada, dos impulsos da modernização econômica calcada no projeto neoliberal. Com isso, os agentes hegemônicos do mercado nacional passaram a seguir, de modo mais veemente do que antes, determinações de agentes internacionais, adotando novos padrões organizacionais e tecnológicos e novas formas de organização social do trabalho. Visando reduzir custos decorrentes do processo produtivo, aqueles agentes sociais lançaram mão da informatização produtiva, obtendo sucesso na redução do número de trabalhadores, na intensificação da jornada de trabalho e na elevação da produtividade com a ajuda dos Círculos de Controle de Qualidade (CCQ's) (ANTUNES, 2006, 2010).

$\mathrm{Na}$ década de 1990, adensou-se a modernização econômica do território brasileiro, com a adesão seletiva, mas menos limitada, de vários receituários oriundos da acumulação flexível de capital. Assim, foi intensificada a linha de produção, banalizada a qualidade total do processo produtivo e expandidas as estratégias de elevação dos lucros dos agentes hegemônicos do mercado, como a subcontratação ou a terceirização de trabalhadores. Além disso, empresas de atuação global passaram a investir mais na desconcentração produtiva, realocando etapas de seu processo produtivo sob o escopo da maior competitividade no mercado internacional, privilegiando, desse modo, territórios que lhes oferecessem maior liberdade e mais vantagens na superexploração do trabalho (ANTUNES, 2010).

Assim, Henrique (1999) elenca fatores determinantes para a precarização do mercado de trabalho nacional na década de 1990, em diferentes ramos de atividades econômicas, a saber: na construção civil, houve paralisação de investimentos em obras públicas e ausência de reordenamento do sistema de financiamento à moradia; no comércio e nos serviços, ocorreu aumento da concentração bancária, privatização de bancos estaduais e difusão rápida de técnicas poupadoras de mão de obra em atividades comerciais e de serviços; na administração pública, destacou-se o aprofundamento da crise financeira do Estado, com a realização de reformas administrativas alicerçadas no próprio desmonte do Estado, eliminando-se, assim, mais de 408 mil postos de emprego no período 19901997.

Sendo assim, atentando para a precarização do trabalho para estudar a desigualdade no Brasil, Henrique (1999) caracteriza as décadas de 1980 e 1990 como aquelas em que se derrocou fortemente o movimento de crítica do "ajuste exportador" e de defesa de reformas estruturais no que tange às instâncias social e econômica, tudo isso sendo implementado pelo avanço do conservadorismo político e do neoliberalismo econômico. Nesse sentido, na aurora do século XXI, as relações e o mercado de trabalho no país já estavam acentuadamente precarizados, com a maioria dos trabalhadores nacionais vivendo em grave situação de pobreza.

Aliás, no decorrer da primeira década do século atual, continuou a efervescência do processo de precarização do trabalho no país, assim como ocorre nos dias de hoje do capitalismo no Brasil (ANTUNES, 2010). Continuam a se combinar transformações técnicas no processo produtivo ou na organização de atividades comerciais ou prestadoras de serviços com a diminuição da força de trabalho ou a flexibilização das relações de trabalho, no sentido de minimizar os rendimentos e os direitos dos trabalhadores, a fim de elevar os lucros e a competitividade dos empregadores. Sendo assim, hoje, a precarização do trabalho é um processo onipresente no território nacional, bem como marcante na situação de

Estudos Geográficos, Rio Claro, 16(2): 5-30, jul./dez. 2018 (ISSN 1678-698X) http://www.periodicos.rc.biblioteca.unesp.br/index.php/estgeo 
labor da grande maioria dos trabalhadores, sejam eles qualificados ou não, ou mesmo empregados ou apenas ocupados.

Do mesmo modo como ocorreu no período entre as décadas de 1950 e 1970, no primeiro decênio do século XXI a precarização do trabalho continuou a ser produzida num contexto de crescimento econômico considerável. Sobretudo a partir de 2006, o Estado investiu na redução de juros, provocando a energização das dinâmicas interna e externa do mercado brasileiro, com a elevação do consumo no âmbito interno e a ampliação de investimentos externos no território nacional.

O bom desempenho da economia nacional acarretou certa recuperação do mercado de trabalho em termos econômicos, cujos aspectos principais, segundo Corrêa (2010), foram: maior tendência ao assalariamento dos trabalhadores, mesmo daqueles empregados precariamente; maior formalização de vínculos ocupacionais, podendo, assim, serem considerados como vínculos empregatícios ou, de maneira mais fiel à realidade, "vínculos empregatícios precários"; o aumento desses vínculos em estabelecimentos registrados junto ao poder público; e o aumento da taxa de ocupados na PEA brasileira.

Todavia essa recuperação do mercado de trabalho no Brasil ocorreu mantendo a precarização das condições de trabalho, já que não foram alterados os baixos rendimentos dos trabalhadores, mas, ao contrário, passou-se a exigir deles maior qualificação e polivalência ${ }^{9}$. Do mesmo modo, os postos de emprego gerados pelo bom desempenho da economia foram, predominantemente, de atividades com grande rotatividade da mão de obra contratada, como a construção civil, não oferecendo nenhuma segurança aos trabalhadores de ficarem empregados por um longo tempo (CAMARGO, 2006; SILVA FILHO; CLEMENTINO, 2013). Além disso, a ampliação do assalariamento aconteceu, na maioria das vezes, não formalizada, isto é, sem o registro em carteira de trabalho (CORRÊA, 2010), ou de maneira parcial, com o empregador garantindo ao empregado alguns direitos trabalhistas, como pagamento do salário-mínimo, mas negando-lhe a integralidade de outros, como o $13^{\circ}$ salário ou o FGTS.

Também é mister sublinhar que a recuperação do mercado de trabalho no país ocorreu de maneira limitada, socioterritorialmente falando. O aumento dos empregos ou das ocupações assalariadas foi substancial apenas no sudeste da Região Concentrada e referente a alguns trabalhadores, como "[...] profissionais de nível superior, trabalhadores manuais na produção de bens e pessoal de apoio administrativo" (CORRÊA, 2010, p. 34). Nas outras regiões e para os outros segmentos do mundo do trabalho brasileiro, o que prevaleceu foi a continuidade, ou mesmo a intensificação, do emprego e das ocupações precárias como a possibilidade majoritária de sobrevivência. Tal situação é acentuada no Nordeste e na Região Amazônica, onde a expansão do circuito inferior da economia é fato e fator do processo de urbanização.

Sendo assim, fica explicitado que o mero crescimento da economia não é suficiente para melhorar as condições de vida e de labor dos trabalhadores. A precarização do trabalho é mais do que um processo econômico; é também uma opção política do Estado brasileiro, patrocinador da modernização do território nacional de acordo com o projeto neoliberal.

\footnotetext{
${ }^{9}$ Parece-nos que o processo de precarização do trabalho desvaloriza a "rigidez" da ideia de divisão do trabalho proposta por Durkheim ([1930] 1999, p. 06): "Coloca-te em condições de cumprir proveitosamente uma função determinada". Hoje, exige-se que o trabalhador seja polivalente, especialista em dada função, mas sabedor de outras funções, com certa habilidade e competência. Conquanto priorize o trabalhador polivalente, a atual divisão do trabalho continua a fazer de cada agente social um trabalhador "incompleto", na medida em que os circuitos econômicos se constituem na solidariedade orgânica e organizacional.

Estudos Geográficos, Rio Claro, 16(2): 5-30, jul./dez. 2018 (ISSN 1678-698X) http://www.periodicos.rc.biblioteca.unesp.br/index.php/estgeo
} 


\section{A FLEXIBILIZAÇÃO DA REGULAÇÃO ESTATAL DO TRABALHO NO BRASIL}

A Organização Internacional do Trabalho (OIT) propugna, em seu sítio na internet, a regulamentação estatal do trabalho tendo como pilares a garantia de proteção especial aos trabalhadores, por eles serem o lado frágil nas relações com os empregadores, e a atenção à função social do trabalho, não o considerando como mera mercadoria. No Brasil tais pilares não são adotados de modo irrestrito e não frágil. Segundo Kowarick (2002, p. 16), no país "[...] jamais houve instituições políticas, sindicais ou comunitárias com força suficiente para garantir a efetivação de direitos básicos do mundo do trabalho ou proteger das intempéries do mundo urbano o morador, transeunte e usuário de serviços básicos".

Apesar de concordamos com tal concepção, é importante destacarmos que houve, no Brasil, dois períodos em que foram implementadas ações estatais no sentido de estabelecer garantias aos trabalhadores, a saber: o período de 19301950, quando foram criadas instituições e institucionalizações para regulamentar formalmente o trabalho, conforme já analisamos neste texto; e o período de elaboração e promulgação da Constituição de 1988, quando se colocou em tela o "esboço de um Estado social no Brasil" (FAGNANI, 2005).

A importância da Constituição de 1988 para o esboço de um Estado cujas ações tivessem como pilar fundamental a instância social deve-se ao fato de esse documento, originalmente, ter como princípios a seguridade social e o direito à cidadania para a universalidade dos brasileiros, sem exceção. Sem emendas, essa Constituição contrapunha-se às ações caritativas e meramente assistencialistas de combate à pobreza, bem como aos privilégios sociais focalizados em determinados segmentos ou agentes sociais hegemônicos.

Todavia, desde a década de 1990, estão vigentes no governo democrático do país ações políticas socialmente conservadoras e mercadologicamente liberais, as quais desmontam as instituições e institucionalizações trabalhistas criadas entre 1930 e 1950 e emendam a Constituição de 1988, tornando-a um documento que reconhece a flexibilização da regulação estatal do trabalho como estratégia imprescindível para integrar interesses internacionais à dinâmica do território nacional, na medida em que confere mais e maior autonomia às empresas do capital hegemônico.

As referidas ideias asseveram que a flexibilização do mercado de trabalho é imprescindível para que o país possa ter condições de competitividade com outros países cuja proteção social já é extremamente precária ou mesmo inexistente. Assim, responsabilizam a legislação trabalhista e o sistema de proteção social brasileiro, pensados há décadas e consolidados na Constituição de 1988, como os fatores determinantes para o "problemático mercado de trabalho nacional" (KREIN, 2007).

Assim, foi trazida à tona a Lei $n^{\circ}$ 9.601, de 1998, que deu liberdade aos empregadores para a contratação de empregados por tempo determinado e com redução de encargos a pagar ${ }^{10}$. Além disso, estabeleceu que as negociações de

\footnotetext{
10 “A Lei n n $^{9} .601$, de 1998, permite às empresas, mediante acordo ou convenção coletiva, contratar trabalhadores por prazo determinado, para qualquer atividade desenvolvida pela empresa ou estabelecimento, conquanto estas admissões representem acréscimo no número de empregados. Tal modalidade de contratação possibilita a redução de $50 \%$ no valor das alíquotas das contribuições sociais destinadas ao Sistema S, INCRA, salário educação e para o financiamento do seguro acidente de trabalho, bem como a redução para $2 \%$ na alíquota da contribuição para o Fundo de Garantia do Tempo de Serviço - FGTS, que normalmente é de 8\%" (SILVA et al. 2002, s.p.).

Estudos Geográficos, Rio Claro, 16(2): 5-30, jul./dez. $2018 \quad$ (ISSN 1678-698X) http://www.periodicos.rc.biblioteca.unesp.br/index.php/estgeo
} 
conflitos de interesses referentes às relações de trabalho deveriam ser realizadas diretamente entre empregador e empregado, sem a necessária mediação estatal, sendo que tais agentes deveriam ser considerados livres e iguais nas negociações. Esse novo padrão de formulação de acordo entre patrão e trabalhadores serviu para amplificar o poder discricionário do empregador, que passou a estabelecer unilateralmente as condições de contratação e remuneração dos empregados, fato que escancarou a fragilidade da regulação pública do mercado de trabalho e o conluio do Estado com os agentes hegemônicos do capital na mercantilização da força de trabalho.

Outrossim, em 2004, propôs-se o Projeto de Lei $n^{\circ} 4330$, que dispõe sobre o contrato de prestação de serviço a terceiros e as relações de trabalho dele decorrentes. Esse projeto ficou parado no Congresso Nacional até início de 2015, quando a maioria dos deputados decidiu aproveitar-se da problemática conjuntura política enfrentada pelo Partido dos Trabalhadores (PT) para aprovar o projeto, que atende o capital contra o trabalho. Aliado a esse fato, Antunes (2015) destaca que a disposição de aprovar esse projeto decorre da negligência do PT no Executivo Federal para com os trabalhadores, optando por governar o país consubstanciado a uma aliança, sobretudo, com os interesses de agentes hegemônicos do capital. Por isso, nos governos Lula (2003-2010) e Dilma (2011-2016), a terceirização saltou de 4 milhões para 12,7 milhões de trabalhadores.

Antunes (2015, s.p.) argumenta que a aprovação desse projeto pelo Senado e sua sanção pela Presidência fundamentará a terceirização global do trabalho, o que, certamente, intensificará a redução de salários, de direitos trabalhistas, o aumento da rotatividade dos trabalhadores em empregos ou ocupações, a demissão mais fácil de trabalhadores e a dificuldade de se organizarem em sindicatos. Assim, "rasga-se a CLT como código do trabalho no Brasil", regredindo-se "à escravidão do trabalho no país, a uma espécie de escravidão moderna, típica de nosso tempo, onde a burla de nossos direitos" é imposta.

Em 2017, no contexto de instabilidade econômica e política do Brasil, o Congresso Nacional aprovou uma reforma trabalhista fundamentada na amplificação da legalização da precarização do trabalho. Isso por que a reforma aprovada privilegia "negociações" a serem feitas entre trabalhador e empregador, sem a necessidade de homologações ou de contratos. Por exemplo, pelas novas regras, no que se refere à remuneração dos trabalhadores, fica desobrigado o pagamento de piso ou de salário mínimo na remuneração por produção, assim como trabalhadores e empresas poderão negociar todas as formas de remuneração. Outrossim, no que tange a plano de cargos e salários, poderão haver negociações entre patrões e trabalhadores sem necessidade de homologação legal, nem de registro em contrato, sendo que o plano de cargos e salários poderá ser mudado a qualquer momento. Destarte, a reforma trabalhista aprovada pelo Congresso Brasileiro vai de encontro ao que determina a OIT, quando propugna a proteção dos mais "fracos" nas relações trabalhistas, isto é, dos trabalhadores. Ao contrário, na atualidade, a maioria dos congressistas brasileiros considera o trabalho apenas como mercadoria e negligencia a sua função social.

Sendo assim, o conservadorismo político no Brasil vem, ora mais ora menos, servindo para conferir autorregulação ao mercado, ao reduzir a dependência dos empregadores da força de trabalho, aumentar a subordinação desta àqueles e diminuir o custo da contratação de empregados, minimizando bastante o impacto do chamado "custo Brasil" na lucratividade dos detentores dos meios de produção, tudo

Estudos Geográficos, Rio Claro, 16(2): 5-30, jul./dez. 2018 (ISSN 1678-698X) http://www.periodicos.rc.biblioteca.unesp.br/index.php/estgeo 
isso às custas da insegurança, da instabilidade e, em suma, da precariedade do trabalho.

De tal modo, Telles (1993) assegura que a flexibilização da regulação estatal do trabalho no Brasil faz do trabalhador, sobretudo do pobre, um agente social carente de condições materiais de vida e privado de direitos sociais.

\section{À GUISA DE CONCLUSÃO: $O$ DESEMPREGO ESTRUTURAL COMO CARACTERÍSTICA DO PROCESSO DE PRECARIZAÇÃO DO TRABALHO NO BRASIL, NO RIO GRANDE DO NORTE E NO EIXO RODOVIÁRIO NATAL- CAICÓ}

O desemprego é um aspecto recente do mercado de trabalho brasileiro. Até a década de 1980, a taxa de desemprego não era substancial no país e o desemprego era limitado, sobretudo, aos segmentos mais vulneráveis da população economicamente ativa, como jovens, negros e mulheres com baixa escolaridade. A partir da década de 1990, com a abertura total do território nacional aos imperativos neoliberais, houve crescimento rápido e generalizado do desemprego, de tal forma que, na atualidade, a taxa de desemprego "[...] continua em patamar elevado - cerca de três a quatro vezes mais alta que as taxas registradas nas décadas de 1970 e 1980 [...]" (POCHMANN, 2008, p. 35), e o desemprego não é mais limitado aos trabalhadores mais vulneráveis, caracterizando também a situação dos trabalhadores com qualificação profissional.

Para os trabalhadores sem escolaridade ou com pouca qualificação, os agentes hegemônicos do mercado alegam que o desenvolvimento técnico exige mais qualificação profissional dos empregados, negando-lhes, assim, o ingresso no mercado de trabalho de maneira formal. Assim, resta-lhes, na maioria das vezes, o desenvolvimento de atividades do circuito inferior da economia urbana, por suas características organizacionais valorizarem mais a intensidade de trabalho e de criatividade, do que a de capital, de normas burocráticas ou de conhecimentos curriculares prementes ao trabalho no circuito superior. Para os trabalhadores com escolaridade ou mais qualificados, tais agentes hegemônicos procuram substituir, crescentemente, o emprego por projetos e campos de atuação profissional, embora façam com que eles continuem agindo de maneira submissa às suas determinações (KREIN, 2007).

O desemprego pode ser conjuntural ou estrutural. O conjuntural se associa a uma dada situação da atividade econômica empregadora, que pode passar por dificuldades ou buscar redução de custos para elevar sua lucratividade, lançando mão, desse modo, do desemprego de trabalhadores como estratégia para melhorar sua situação ou atingir seus objetivos econômicos. Assim, diz-se que o desemprego conjuntural se conecta mais à microeconomia, ou seja, ao funcionamento e à organização das empresas, podendo ser revertido com a transformação positiva da situação econômica das atividades empregadoras.

Já o desemprego estrutural particulariza-se pela longa duração do não emprego dos trabalhadores desempregados ou jamais empregados pelos agentes hegemônicos do mercado, relacionando-se à macroeconomia, isto é, ao ritmo de expansão da economia nacional e à forma como ocorre essa expansão, no que se refere à adoção ou à produção de inovações técnicas e à inserção no contexto

Estudos Geográficos, Rio Claro, 16(2): 5-30, jul./dez. 2018 (ISSN 1678-698X) http://www.periodicos.rc.biblioteca.unesp.br/index.php/estgeo 
mundial. Em termos macroeconômicos, a economia do país pode até crescer, mas, se tal crescimento ocorrer, como no caso do Brasil, de maneira subordinada a interesses internacionais exploradores das riquezas e da força de trabalho nacionais, os postos de trabalho gerados serão precários, pagando baixa remuneração aos trabalhadores e sujeitando-os a péssimas condições de trabalho. Assim, o desemprego estrutural só pode ser combatido com mudanças estruturais no que tange ao desenvolvimento tecnológico adotado nos circuitos econômicos do país, bem como ao relacionamento da economia nacional com o voraz mercado internacional.

No estágio atual do capitalismo brasileiro, o número total de pessoas sem ocupação não vem, com frequência, aumentando. Apesar disso, a geração de trabalho vem ocorrendo juntamente com a deterioração das relações e do mercado de trabalho, de forma que, hoje, "talvez melhor do que a palavra desemprego, seja precarização do trabalho a descrição adequada do que está ocorrendo" (SINGER, 1996, p. 08). Contudo, diante desse contexto, se quisermos falar em desemprego, devemos reconhecer que o desemprego existente no país é, sobretudo, o estrutural, já que a economia nacional vem gerando muito mais ocupações, precárias na sua maioria, do que empregos.

Dito isso, vale diferenciar ocupação e emprego. Singer (1996) esclarece que ocupação é toda forma de atividade que proporciona renda e possibilidade de consumo a quem a exerce, sem que haja, necessariamente, assalariamento do trabalhador e garantia de direitos trabalhistas. Além disso, a ocupação pode ser por conta própria, não havendo relação entre patrão e trabalhador. Emprego é um tipo de ocupação, que, sem flexibilizações, deveria implicar assalariamento e garantia de direitos sociais ao trabalhador empregado. Outrossim, o emprego é sempre uma relação de trabalho, na qual um empregador vincula empregado.

No Brasil, a situação de desemprego pode perdurar por um longo período e, até mesmo, tornar-se praticamente definitiva, levando os trabalhadores desempregados, mas não desocupados, a "se virarem", desenvolvendo ocupações por conta própria ou trabalhando com familiares ou conhecidos, em "estratégias de sobrevivência".

Por meio de tais estratégias, muitos trabalhadores brasileiros vêm dinamizando a economia nacional, sob condições de trabalho precárias. Chamamos as ocupações geradas pelo crescimento econômico brasileiro de "precárias" por elas gerarem baixa remuneração para os trabalhadores que as desenvolvem, não lhes garantirem segurança social alguma e, quando não desenvolvidas por conta própria, constituírem-se em relações de trabalho alicerçadas, geralmente, em acordos verbais, que podem ser rapidamente ou facilmente questionados ou rompidos, diante de dificuldades ou discordâncias, sendo, portanto, relações efêmeras, em sua maioria.

Devido ao fato de os novos postos de trabalho no Brasil não oferecerem, na maioria das vezes, as compensações usuais que deveriam garantir de acordo com leis trabalhistas, Antunes (2013, p. 14) defende que o mercado de trabalho nacional é hoje marcado por uma nova morfologia do trabalho, na qual "[...] o trabalho estável, herdeiro da fase taylorista-fordista, relativamente moldado pela contratação e pela regulamentação, vem sendo substituído pelos mais distintos e diversificados modos de informalidade, por exemplo: o trabalho atípico, os trabalhos terceirizados (com sua enorme gama e variedade), o cooperativismo, o empreendedorismo, o trabalho voluntário etc." (destaques do autor). A nosso ver, essa nova morfologia é evidente na dinâmica socioeconômica do país, mas não deve ter seus "modos mais

Estudos Geográficos, Rio Claro, 16(2): 5-30, jul./dez. 2018 (ISSN 1678-698X) http://www.periodicos.rc.biblioteca.unesp.br/index.php/estgeo 
frequentes de ser" estereotipados como "modos de informalidade", já que o autor usa tal denominação privilegiando as precárias condições e relações de trabalho, e não o registro da atividade ou do empreendedor junto ao poder público. Assim, preferimos denominá-los de "modos de precarização do trabalho", tendo em vista que alguns tipos de trabalho não são informais, perante o Estado nacional, como o empreendedorismo formalizado pela política do MEI.

Dados estatísticos do MTE/RAIS-CAGED (2014) e do IBGE/SIDRA (2014) e dados primários decorrentes da pesquisa que realizamos com agentes do circuito inferior da economia urbana do eixo rodoviário Natal-Caicó evidenciam que a situação nacional de desemprego estrutural com a dinâmica econômica fundamentada, sobretudo, em ocupações precárias é, especificamente, também característica das relações e do mercado de trabalho no Rio Grande do Norte e no referido eixo rodoviário.

Acerca da faixa etária dos trabalhadores com vínculo empregatício, em 1985, no Rio Grande do Norte, a maioria dos empregados tinha de 30 a 39 anos, de 18 a 24 anos ou de 25 a 29 anos; no eixo rodoviário Natal-Caicó, as faixas etárias predominantes eram de 30 a 39 anos, de 25 a 29 anos ou de 18 a 24 anos. Em 1990, no Rio Grande do Norte, os resultados foram os mesmos registrados em 1985; no eixo rodoviário, predominaram os empregados de 30 a 39 anos, de 18 a 24 anos ou de 25 a 29 anos (MTE/RAIS, 2014). No quinquênio, compreendemos ter havido aumento intensivo do número de empregados com idade entre 18 e 29 anos, diminuindo (no eixo Natal-Caicó) ou mantendo-se (no estado) as oportunidades de emprego para os muito jovens (de 10 a 17 anos) e caindo para os de idade mais avançada (a partir dos 50 anos).

Em 2000, no Rio Grande do Norte e no eixo rodoviário Natal-Caicó, a maioria dos empregados tinha de 30 a 39 anos, de 40 a 49 anos ou de 18 a 24 anos (MTE/RAIS, 2014). Em relação a 1990, houve intensa diminuição das oportunidades de emprego para os mais jovens (de 10 a 14 anos, de 18 a 29 anos e, no estado, de 15 a 17 anos) e, em contrapartida, aumento do número de empregados com idade a partir dos 30 anos, inclusive para os mais experientes (50 anos ou mais). Destarte, na referida década, o mercado de trabalho formalizado ficou mais maduro e menos jovem.

Em 2012, no Rio Grande do Norte e no eixo rodoviário Natal-Caicó, a maioria dos empregados tinha de 30 a 39 anos, de 40 a 49 anos ou de 50 a 64 anos, o que ratifica a maturidade do mercado de trabalho formalizado (MTE/RAIS, 2014). Além disso, na série 2000-2012, com exceção das faixas de 10 a 14 anos e de 15 a 17 anos, que registraram crescimento moderado ou estagnação nos dados, houve intenso aumento do número de empregados em todas as outras faixas etárias, dado que pode ser relacionado ao do aumento considerável no número de empregos no mesmo período.

A maturidade dos empregados no Rio Grande do Norte e no eixo rodoviário Natal-Caicó, mostrada pelos dados do MTE/RAIS (2014) também existia no circuito inferior da economia urbana do eixo em questão, cuja maioria $(69,6 \%)$ de trabalhadores, em todas as cidades, era de adultos, isto é, com idade a partir de 30 anos. Além disso, devido às dificuldades encontradas pelos mais jovens para ingressar no mercado de trabalho formalizado, alguns (19,6\%) agentes do circuito inferior do eixo rodoviário tinham entre 15 e 24 anos, apresentando-se, geralmente, como trabalhadores que ingressaram no mercado de trabalho já via economia não hegemônica e que, portanto, aguardavam melhores possibilidades de trabalho ou de renda para poderem estudar mais e constituir família.

Estudos Geográficos, Rio Claro, 16(2): 5-30, jul./dez. 2018 (ISSN 1678-698X) http://www.periodicos.rc.biblioteca.unesp.br/index.php/estgeo 
Visando levantar dados sobre a quantidade de empregados e de ocupados no Rio Grande do Norte e no eixo rodoviário Natal-Caicó, cruzamos dados do MTE/RAIS (2014), sobre a quantidade de vínculos empregatícios sob regime CLT ou Estatutário, com dados do IBGE/SIDRA (2014), acerca do total do pessoal ocupado. Esse cruzamento revelou que há discrepâncias entre os dados do MTE/RAIS e os do IBGE/SIDRA, havendo municípios em que o número total de pessoal ocupado é menor do que o número de trabalhadores empregados sob regime CLT ou Estatutário. Tais discrepâncias comprometem a análise feita a partir desses dados. Não obstante, apreendemos que, entre 2006 e 2012, no eixo rodoviário Natal-Caicó, além da elevação do número de empregos sob regime CLT ou Estatutário, aumentou também o número de trabalhadores ocupados sem o vínculo com esses regimes, dados que indicam a amplificação conjunta de empregos e de trabalhos regidos por contratos flexíveis ou não regulamentados sob as leis trabalhistas.

Devido essas discrepâncias de dados, cruzamos também dados do MTE/RAIS sobre a quantidade de vínculos empregatícios sob regime CLT ou Estatutário com dados do IBGE/SIDRA sobre a população economicamente ativa na semana de referência dos censos demográficos 2000 e 2010. Nesse cruzamento, não foram evidenciadas incoerências entre os dados.

Assim, compreendemos que, no eixo rodoviário Natal-Caicó, entre 2000 e 2010, o número de empregos cresceu em todos os municípios e, em geral, de forma mais intensa do que a elevação da PEA. Assim, no período analisado, diminuiu a quantidade de pessoas economicamente ativas sem vínculo trabalhista sob regime CLT ou Estatutário. Apesar disso, em 2010, no eixo rodoviário em estudo havia 251.986 trabalhadores nessa situação.

No Rio Grande do Norte, apesar de a quantidade de empregos também ter sido ampliada entre 2000 e 2010, houve elevação do número de trabalhadores economicamente ativos não empregados.

Diante do apontamento de crescimento do número de empregos no Rio Grande do Norte e no eixo rodoviário Natal-Caicó, é importante analisarmos os tipos de vínculos trabalhistas que vêm sendo gerados, bem como sua qualidade no que tange à garantia de direitos sociais, ao nível de remuneração pago aos trabalhadores, ao tempo médio de permanência dos trabalhadores no emprego e à intensidade de sua jornada de trabalho.

Sobre os tipos dos vínculos gerados, entre 1985 e 1990, cresceu, no Rio Grande do Norte e no eixo rodoviário Natal-Caicó, o número de vínculos ativos sob regime CLT ou Estatutário. A despeito da diminuição do número de trabalhadores temporários, aumentou também a quantidade de trabalhadores avulsos, que são os que prestavam serviços a empresas ou a pessoas físicas sem ter vínculo empregatício, embora com a intermediação de um sindicato ou órgão gestor de mão de obra; aumentou também a quantidade de vínculos denominados pelo MTE como "outros" (MTE/RAIS, 2014). Portanto, o referido quinquênio foi marcado pela geração de postos de empregos em atividades formalizadas, muitos dos quais temporários ou não especificados, fato característico do processo de precarização do trabalho.

Em 2000, no Rio Grande do Norte e no eixo rodoviário Natal-Caicó, a maioria dos empregados eram celetistas urbanos contratados por empresas em período indeterminado, seguidos pelos estatutários. Destacamos que havia vários trabalhadores contratados de maneira não efetiva (estatutário não efetivo), sem vínculo empregatício (avulso) ou por um prazo "determinado" (pode-se entender temporário) (tipos: aprendiz, temporário, CLT U/ PJ Determinado, CLT U/ PF Determinado, CLT R/ PJ Determinado, CLT R/ PF Determinado, Contrat Prazo

Estudos Geográficos, Rio Claro, 16(2): 5-30, jul./dez. 2018 (ISSN 1678-698X) http://www.periodicos.rc.biblioteca.unesp.br/index.php/estgeo 
Determinado): no Rio Grande do Norte, somados 15.934 trabalhadores; no eixo rodoviário Natal-Caicó, 7.909 trabalhadores (MTE/RAIS, 2014). Eram vínculos empregatícios temporários ou mesmo ocupações sem vínculo empregatício geradas por atividades formalizadas.

Em 2012, no Rio Grande do Norte e no eixo rodoviário Natal-Caicó, aumentou, em relação a 2000, o número de empregados celetistas urbanos contratados por empresa em período indeterminado, continuando esses trabalhadores a ser a maioria dos empregados nos referidos territórios. Do mesmo modo, aumentou consideravelmente o número de Estatutários, os quais se mantiveram na segunda posição no número de empregados. Além disso, amplificouse também o número de trabalhadores temporários ou sem vínculo empregatício nas atividades formalizadas, a saber: no Rio Grande do Norte, 34.821 trabalhadores; no eixo rodoviário Natal-Caicó, 15.348 trabalhadores (MTE/RAIS, 2014).

A garantia ou não de direitos sociais aos trabalhadores, com registro formal da relação de trabalho, é também um fator salutar para a discussão sobre a precarização do trabalho. De acordo com o IBGE/SIDRA (2014), em 2000 e 2010, no Rio Grande do Norte e no eixo rodoviário Natal-Caicó, a maioria dos trabalhadores tinha registro em carteira de trabalho. Todavia, no eixo rodoviário, essa maioria decorria da complexidade do mercado de trabalho da capital do estado, das cidades da Região Metropolitana de Natal $^{11}$ (RMN) e dos centros regionais sertanejos $^{12}$, onde há densidade de empregos. Nos centros locais ${ }^{13}$, onde existe rarefação de vínculos empregatícios, a maioria dos trabalhadores desempenhava ocupações sem carteira de trabalho assinada e sem contribuição para a previdência. Sendo assim, asseveramos que o nível de complexidade do conteúdo do território usado condiciona a garantia ou não de direitos sociais aos trabalhadores empregados ou ocupados.

No que se refere à remuneração dos empregados, destacamos que, em 1985, no Rio Grande do Norte e no eixo rodoviário Natal-Caicó, a grande maioria percebia de 1,01 a 2 salários mínimos; muitos recebiam de 2,01 a 3 ou de 0,51 a 1 salário. Em 1990, tanto no estado quanto no eixo rodoviário, a grande maioria dos trabalhadores continuou recebendo de 1,01 a 2 salários-mínimos (MTE/RAIS, 2014). No entanto, no quinquênio, destacamos que houve diminuição do número de empregados que recebiam até dois salários-mínimos e o aumento daqueles que

\footnotetext{
11 “Criada em 1997 pela Lei Complementar Estadual nº. 152/97, a Região Metropolitana (RM) de Natal é composta por onze municípios [Ceará-Mirim, Extremoz, Macaíba, Maxaranguape, Monte Alegre, Natal, Nísia Floresta, Parnamirim, São Gonçalo do Amarante, São José de Mipibu e Vera Cruz] e possui área de $2.808 \mathrm{~km}^{2}$. Em 2010, a RM de Natal possuía um grau de urbanização de $90 \%$ e cerca de $43 \%$ da população estadual residia na RM. A população do município-núcleo, Natal, da RM correspondia, em 2010, a 63\% da população metropolitana. A taxa de crescimento da população da RM de Natal, entre 2000 e 2010, foi de 1,86\% ao ano" (IPEA/Região Metropolitana de Natal, 2016, p. 68).

Dados do último censo do IBGE mostram que as maiores cidades da RMN são, respectivamente: Natal, Parnamirim, São Gonçalo do Amarante, Macaíba e Ceará-Mirim. Além disso, os dados evidenciam que as cidades que mais crescem são Parnamirim, São Gonçalo do Amarante, Macaíba e Extremoz, as quais fazem fronteira com a capital do estado e, desse modo, são direta e fortemente influenciadas pela dissolução geográfica de funcionalidades de Natal na rede urbana potiguar. As cidades da RMN que integram o eixo rodoviário Natal-Caicó são: Natal, Parnamirim e Macaíba.

${ }^{12}$ Centros regionais sertanejos são importantes cidades do interior potiguar, que ofertam uma maior quantidade de bens e serviços e localizam serviços com melhor qualidade do que os encontrados nos centros locais, fatos que conectam suas funções à intermediação da produção e/ou do consumo na rede de relações urbanas. No eixo rodoviário Natal-Caicó os centros regionais sertanejos são: Santa Cruz - principal cidade da Mesorregião do Agreste Potiguar -, Currais Novos e Caicó, principais cidades do Seridó Potiguar.

${ }^{13}$ Nosso entendimento de centro local é tributário da concepção de Santos (2008) sobre cidade local: aglomeração capaz de responder às necessidades vitais mínimas de dada população. Nessa perspectiva, asseveramos que a cidade local se apresenta como centro funcional imediato da área rural que a circunda, mas não como centro dinâmico da região que integra, devido a sua frágil complexidade funcional. No eixo rodoviário Natal-Caicó os centros urbanos locais são: Bom Jesus, Senador Elói de Souza, Tangará, Campo Redondo, Acari e Jardim do Seridó.

Estudos Geográficos, Rio Claro, 16(2): 5-30, jul./dez. 2018 (ISSN 1678-698X)
} http://www.periodicos.rc.biblioteca.unesp.br/index.php/estgeo 
percebiam maiores rendimentos. Realçamos a estabilização, no eixo rodoviário, e o aumento, no Rio Grande do Norte, da remuneração denominada como "não classificada". Talvez essa denominação remeta para a existência de trabalhadores sem remuneração determinada.

Em 2000, no Rio Grande do Norte e no eixo rodoviário Natal-Caicó, a maioria dos empregados continuava a receber de 1,01 a 2 salários mínimos mensais. O desmembramento de dados coletados pelo MTE permite afirmar que, desses trabalhadores, a grande maioria percebia de 1,01 a 1,50 salário-mínimo. Logo após, destacou-se a faixa salarial de 2,01 a 3 salários-mínimos. Em 2012, a análise dos dados é idêntica à realizada para 2000 (MTE/RAIS, 2014). Na série histórica, destacamos o crescimento intenso do número de empregados nas faixas de remuneração de até 4 salários, bem como para os rendimentos não classificados. Acima de quatro salários, o crescimento foi moderado, sendo negativo na faixa de mais de 20 salários-mínimos mensais. Assim, entendemos ter havido denso crescimento dos empregos de baixos rendimentos.

Em 2013, no estado e no eixo rodoviário, a maioria dos empregados continuava a receber mensalmente de 1,01 a 1,5 salário. Diferentemente de 2012, logo após, estava a faixa salarial de 0,51 a 1 salário-mínimo mensal, dados que apontam para queda nos rendimentos da grande maioria dos empregados. As estatísticas iniciais para o ano de 2014 confirmam essa tendência, no estado e no eixo Natal-Caicó (MTE/CAGED, 2014).

À propósito da remuneração de todos os trabalhadores, empregados ou não, em 2000 e 2010, a maioria dos trabalhadores do Rio Grande do Norte e do eixo rodoviário Natal-Caicó tinha rendimento de mais de $1 / 2$ a 1 salário-mínimo. Apenas na capital potiguar, em toda a série histórica, e em Parnamirim, em 2010, a maioria dos trabalhadores recebia mais de 1 a 2 salários-mínimos; em todas as outras cidades estudadas, o rendimento majoritário não ultrapassava 1 salário-mínimo mensal. No que diz respeito aos dados de 2010 , destacamos o elevado número de pessoas ocupadas sem rendimento, em municípios do eixo rodoviário bem como no estado (IBGE/SIDRA, 2014), o que, para nós, se refere a trabalhadores que ajudam seus familiares no desenvolvimento de atividades econômicas não hegemônicas. Tais trabalhadores, geralmente, não têm rendimento nominal médio mensal definido, tendo em vista agirem voluntariamente visando à geração de renda mensal familiar.

A despeito do tempo de permanência dos trabalhadores no emprego, dados do MTE/RAIS (2014) mostram que, em 1985, no Rio Grande do Norte e no eixo rodoviário Natal-Caicó, a maioria dos trabalhadores permanecia no emprego por mais de 5 anos. Entretanto, também havia muitos (49.498 e 33.384 trabalhadores, respectivamente) que não permaneciam um ano no emprego. Em 1990, novamente, a maioria dos trabalhadores do estado e do eixo rodoviário permanecia no emprego por mais de 5 anos. No quinquênio, há de se destacar, no que se refere ao eixo Natal-Caicó, a diminuição do número de trabalhadores que não chegavam a ficar no emprego um ano (30.391 trabalhadores); no Rio Grande do Norte, esse número (49.500 trabalhadores) ficou, praticamente, estabilizado em relação a 1985. Ao contrário, cresceu consideravelmente o número de empregados que estavam vinculados por mais de 10 anos.

Em 2000, no Rio Grande do Norte e no eixo rodoviário Natal-Caicó, a grande maioria dos trabalhadores permanecia no emprego por 10 anos ou mais. No entanto, em relação a 1990, cresceu o número de trabalhadores (48.521 e 83.224, respectivamente) que não chegavam a permanecer no emprego por um ano. Em 2012, no estado e no eixo, manteve-se a maioria significativa de trabalhadores que

Estudos Geográficos, Rio Claro, 16(2): 5-30, jul./dez. 2018 (ISSN 1678-698X) http://www.periodicos.rc.biblioteca.unesp.br/index.php/estgeo 
permaneciam no emprego por 10 anos ou mais. Na série histórica 2000-2012, cresceu exponencialmente o número de trabalhadores (112.622 e 173.889, respectivamente) que não conseguiram ficar empregados ininterruptamente por um ano (MTE/RAIS, 2014), indicando que a temporalidade nos empregos é um traço marcante do mercado de trabalho contemporâneo.

A efemeridade da permanência dos trabalhadores no emprego na atualidade é ratificada com os seguintes dados do MTE/CAGED (2014): Em 2013, no Rio Grande do Norte e no eixo rodoviário Natal-Caicó, a grande maioria dos trabalhadores não conseguiu ficar empregada nem por um mês. Outrossim, respectivamente 297.198 e 193.088 trabalhadores não conseguiram ficar empregados por pelo menos um ano; aumento vertiginoso desse dado registrado em 2012. Os dados iniciais para o ano de 2014 vão ao encontro da confirmação da fugacidade da maioria dos empregos hoje existentes.

Essa fugacidade também é demonstrada pelos dados do MTE/CAGED (2014) sobre a movimentação de empregados admitidos e desligados: No Rio Grande do Norte e no eixo rodoviário Natal-Caicó, entre 2010 e 2014, o número de empregados admitidos sempre foi levemente maior que o de desligados; contudo, na série histórica, o número de desligados se expandiu mais intensamente que o de admitidos.

Ainda explicitando dados sobre a qualidade dos empregos existentes no território estudado, sublinhamos que, entre 2000 e 2014, tanto no Rio Grande do Norte quanto no eixo rodoviário Natal-Caicó, a grande maioria dos empregados trabalhava de 41 a 44 horas semanais (MTE/RAIS/CAGED, 2014), isto é, de segunda a sexta-feira nos turnos matutino e vespertino e, ao sábado, no turno matutino, ficando "livres" para realizar ações não laborativas do sábado à tarde até o domingo à noite. Entretanto, diante dos baixos rendimentos recebidos, destacamos que muitos empregados utilizavam esse período de "liberdade" do seu emprego para desempenhar ocupações extra visando aumentar a renda mensal de sua família, sendo que, na maioria das vezes, desenvolviam tarefas por conta própria relacionadas às que desempenhavam cotidianamente em seu emprego ou ajudavam seus familiares no desenvolvimento de atividade não hegemônica.

No que se refere às atividades que mais empregam e mais ocupam trabalhadores no Rio Grande do Norte e no eixo rodoviário, as atividades comerciais e as de serviços são as que mais vêm empregando trabalhadores. Também havia muitos trabalhadores que desempenhavam atividades produtivas. Em 2010, com a adoção de outra classificação de ocupações, os dados do IBGE/SIDRA indicam que a maioria dos trabalhadores continuava prestando serviços ou desenvolvendo comércio, assim como muitos sobreviviam com as chamadas "ocupações elementares", aquelas que não exigem altos níveis de capital, tecnologia, organização e qualificação para serem desempenhadas. Portanto, são números que remetem à importância do circuito inferior na economia urbana potiguar e, particularmente, do eixo Natal-Caicó.

Aliás, a importância do circuito inferior na economia urbana é reveladora da precária situação do trabalho no território estudado. Conforme analisamos, vem ocorrendo geração de empregos no eixo rodoviário Natal-Caicó, mas falta qualidade a esses empregos, tendo-se em vista que eles nem sempre garantem direitos sociais aos trabalhadores empregados, remuneram mal a maioria deles, apesar de Ihes exigir mais qualificação do que outrora, são efêmeros quanto ao tempo em que os trabalhadores permanecem empregados e, mesmo assim, determinam dedicação quase exclusiva no decorrer da semana dos trabalhadores. Além disso, a

Estudos Geográficos, Rio Claro, 16(2): 5-30, jul./dez. 2018 (ISSN 1678-698X) http://www.periodicos.rc.biblioteca.unesp.br/index.php/estgeo 
quantidade de empregos gerados não atende à demanda total por trabalho da população economicamente ativa. Destarte, há muitos trabalhadores desempregados, sendo que alguns nunca estiveram empregados, já ingressando no mercado de trabalho por meio de ocupações do circuito inferior da economia urbana. É uma situação extremamente precária, na qual o desemprego perdura, contribui para a expansão do circuito inferior e, a nosso ver, também alicerça a produção da nova pobreza, igualmente estrutural, na medida em que, ao buscarem sua sobrevivência por ocupações precárias, os trabalhadores pobres se relacionam com a economia hegemônica de modo bastante subordinado, incorporando variáveischave do período em suas ações e, assim, ampliando a acumulação flexível de capital pelos agentes hegemônicos do mercado.

\section{REFERÊNCIAS}

ABÍLIO, L. C. O make up do trabalho: uma empresa e um milhão de revendedoras de cosméticos. 2011. Tese (Doutorado em Ciências Sociais) - Universidade Estadual de Campinas, Campinas.

ALVES, M. A. "Setor informal" ou "trabalho informal"? Uma abordagem crítica sobre o conceito de informalidade. 2001. Dissertação (Mestrado em Sociologia) Universidade Estadual de Campinas, Campinas.

ANTUNES, R. Adeus ao trabalho? Ensaio sobre as metamorfoses e a centralidade do mundo do trabalho. São Paulo: Cortez; Campinas: EDUNICAMP, 1998.

ANTUNES, R. A era da informatização e a época da informalização: riqueza e miséria do trabalho no Brasil. In: Riqueza e miséria do trabalho no Brasil. São Paulo: Boitempo, 2006. p. 15-35.

ANTUNES, R. Anotações sobre o capitalismo recente e a reestruturação produtiva no Brasil. In: ANTUNES, R.; SILVA, M. A. M. (orgs) O avesso do trabalho. São Paulo: Expressão Popular, 2010. p. 13-24.

ANTUNES, R. A nova morfologia do trabalho e suas principais tendências: informalidade, infoproletariado, (i)materialidade e valor. In: Riqueza e miséria do trabalho no Brasil II. São Paulo: Boitempo, 2013. p. 13-27.

ANTUNES, R. O trabalho que estrutura o capital desestrutura a sociedade. Entrevista realizada por Ricardo Machado. Instituto Humanitas Unisinos, 24 abr. 2015.

CAMARGO, F. S. Análise estrutural do emprego formal e informal na economia brasileira. 2006. Dissertação (Mestrado em Economia Aplicada) - Universidade de São Paulo, Piracicaba.

CASTEL, R. As metamorfoses da questão social: uma crônica do salário. Tradução de Iraci D. Poleti. Petrópolis: Vozes, [1995] 2009.

Estudos Geográficos, Rio Claro, 16(2): 5-30, jul./dez. 2018 (ISSN 1678-698X) 
CORRÊA, R. S. O emprego sem carteira de trabalho no Brasil urbano. 2010. Dissertação (Mestrado em Desenvolvimento Econômico) - Universidade Estadual de Campinas, Campinas.

DIAS, H. Acumulação flexível e impactos no mundo do trabalho. Vírus, Revista política e de ideias, n. 01, Il série, jun. 2012.

DRUCK, G. A precarização social do trabalho no Brasil: alguns indicadores. In: ANTUNES, R. (org.) Riqueza e miséria do trabalho no Brasil II. São Paulo: Boitempo, 2013. p. 60-73.

DURKHEIM. E. Da divisão do trabalho social. Tradução de Eduardo Brandão. São Paulo: Martins Fontes, [1930] 1999.

FAGNANI, E. Política social no Brasil (1964-2002): entre a cidadania e a caridade. 2005. Tese (Doutorado em Ciências Econômicas) - Universidade Estadual de Campinas, Campinas.

HENRIQUE, W. O capitalismo selvagem: um estudo sobre desigualdade no Brasil. 1999. Tese (Doutorado em Ciências Econômicas) - Universidade Estadual de Campinas, Campinas.

INSTITUTO BRASILEIRO DE GEOGRAFIA E ESTATÍSTICA (IBGE). Sistema IBGE de recuperação automática (SIDRA). Disponível em: $<$ http://www.sidra.ibge.gov.br/>. Acesso em: 11 mar. 2014.

INSTITUTO DE PESQUISA ECONÔMICA APLICADA (IPEA). Região Metropolitana de Natal. Disponível em: <http://www.ipea.gov.br/agencia/images/sto ries/PDFs/livros/livros/141125 atlas natal>. Acesso em: 19 de outubro de 2016.

ITIKAWA, L. F. Trabalho informal nos espaços públicos no centro de São Paulo: pensando parâmetros para políticas públicas. 2006. Tese (Doutorado em Arquitetura e Urbanismo) - Universidade de São Paulo, São Paulo.

KOWARICK, L. Viver em risco: sobre a vulnerabilidade no Brasil urbano. Novos Estudos CEBRAP, São Paulo, n. 63, p. 09-30, jul. 2002.

KREIN, J. D. Tendências recentes nas relações de emprego no Brasil: 19902005. 2007. Tese (Doutorado em Economia Aplicada) - Universidade Estadual de Campinas, Campinas.

MATTOSO, J. E. L. Trabalho sob fogo cruzado. São Paulo em Perspectiva, v. 8, n. 1, p. 13-21, jan./mar. 1994.

MÉSZÁROS, I. Desemprego e precarização: um grande desafio para a esquerda. In: ANTUNES, R. (org.) Riqueza e miséria do trabalho no Brasil. São Paulo: Boitempo, 2006. p. 36-44. 
MINISTÉRIO DO TRABALHO E EMPREGO (MTE). Relação Anual de Informações Sociais (RAIS). Cadastro Geral de Empregados e Desempregados (CAGED). Disponível em: <http://pdet.mte.gov.br/>. Acesso em: 08 de maio de 2014.

NERI, M. C (Coord.). A nova classe média: o lado brilhante dos pobres. Rio de Janeiro: $\quad 2010.2$ Disponível em: $<$ http://www.cps.fgv.br/ibrecps/ncm2010/NCM Pesquisa FOR MATADA.pdf>. Acesso em: 30 nov. 2014.

OLIVEIRA, D. T. et. al. Uso do território e pobreza urbana na cidade de União dos Palmares - AL. In: XVII ENCONTRO NACIONAL DE GEÓGRAFOS: ESCALAS, PODERES, AÇÕES, GEOGRAFIAS. Anais... Belo Horizonte: UFMG/AGB, 2012.

OLIVEIRA, E. L. Divisão do trabalho e circuitos da economia urbana em Londrina-PR. 2009. Tese (Doutorado em Geografia Humana) - Universidade de São Paulo, São Paulo.

POCHMANN, M. O emprego no desenvolvimento da nação. São Paulo: Boitempo, 2008.

ROCHA, S. Pobreza no Brasil: afinal, de que se trata? Rio de Janeiro: Editora FGV, 2003.

ROCHA, S. Pobreza no Brasil: a evolução de longo prazo (1970-2011). In: XXV FÓRUM NACIONAL O BRASIL DE AMANHÃ: TRANSFORMAR CRISE EM OPORTUNIDADE. Rio de Janeiro, maio de 2013.

SALAMA, P. Riqueza y pobreza en América Latina: la fragilidad de las nuevas políticas económicas. México: Fondo de Cultura Económica, 1999.

SANTOS, B. S. Renovar a teoria crítica e reinventar a emancipação social. Tradução de Mouzar Benedito. São Paulo: Boitempo, 2007.

SANTOS, M. O espaço dividido: os dois circuitos da economia urbana dos países subdesenvolvidos. Rio de Janeiro: Livraria Ed. Francisco Alves, 1978a.

SANTOS, M. Pobreza urbana. São Paulo, Recife: Hucitec, UFPE, Comissão Nacional de Regiões Metropolitanas e Política Urbana, 1978b.

SANTOS, M. Da totalidade ao lugar. São Paulo: Editora da Universidade de São Paulo, 2008.

SENNETT, R. A corrosão do caráter: consequências pessoais do trabalho no novo SILVA, J. L. T. et. al. A informalidade no mercado de trabalho brasileiro e as políticas públicas do governo federal. REUNIÃO DE MINISTROS DO TRABALHO DO MERCOSUL. Salvador, 2002. Disponível em: <http://portal.mte.gov.br/data/files/ FF8080812BA5F4B7012BABBAC51731E4/Informalidade2.pdf>. Acesso em: 21 nov. 2014.capitalismo. Rio de Janeiro: Record, 2005. 
SILVA FILHO, L. A.; CLEMENTINO, M. L. M. Perfil sócio-ocupacional nas regiões metropolitanas do Nordeste brasileiro. Mercator, Fortaleza, v. 12, n. 28, p. 35-53, mai./ago. 2013.

SILVEIRA, M. L. Finanças, consumo e circuitos da economia urbana na cidade de São Paulo. Caderno CRH, Salvador, v. 22, n. 55, p. 65-76, jan./abr. 2009.

SINGER, P. Desemprego e exclusão social. São Paulo em Perspectiva, v. 10, n. 1, p. 03-12, jan./mar. 1996.

SINGER. P. Globalização e desemprego: diagnóstico e alternativas. São Paulo: Contexto, 2003.

SOUZA, M. B. A atualidade do debate da marginalidade social: notas contra 0 predomínio do pragmatismo e do individualismo no estudo das relações de trabalho. In: VI SEMINÁRIO DO TRABALHO: ECONOMIA E EDUCAÇÃO NO SÉCULO XXI. Anais... Marília: UNESP, 2008.

TELLES, V. S. Pobreza e cidadania: dilemas do Brasil contemporâneo. Caderno CRH, 19, Salvador, 1993.

VASAPOLLO, L. O trabalho atípico e a precariedade: elemento estratégico determinante do capital no paradigma pós-fordista. In: ANTUNES, R. (org.) Riqueza e miséria do trabalho no Brasil. São Paulo: Boitempo, 2006. p. 45-58.

ZAOUAL, H. Globalização e diversidade cultural. Textos selecionados e traduzidos por Michel Thiollent. São Paulo: Cortez, 2003.

Artigo submetido em: 09/11/2017

Aceito para publicação em: 23/10/2018

Publicado em: 14/12/2018

Estudos Geográficos, Rio Claro, 16(2): 5-30, jul./dez. 2018 (ISSN 1678-698X) 